\title{
In vitro Assessment of Oxidative Stress and Apoptotic Mechanisms of Garlic Extract in the Treatment of Acute Promyelocytic Leukemia
} Clement G. Yedjou* and Paul B. Tchounwou

Cellomics and Toxicogenomics, Research Laboratory, NIH RCMI-Center for Environmental Health, College of Science, Engineering and Technology, Jackson State University, 1400 Lynch Street, P.O. Box 18540, Jackson, Mississippi, USA

\begin{abstract}
Introduction: Garlic supplementation in diet has been shown to be beneficial to cancer patients. Recently, its pharmacological role in the prevention and treatment of cancer has received increasing attention. However the mechanisms by which garlic extract (GE) induces cytotoxicity, oxidative stress, and apoptosis in cancer cells remain largely unknown.
\end{abstract}

Objective: The present study was designed to use HL-60 cells as a test model to evaluate whether or not GEinduced cytotoxicty and apoptosis in human leukemia (HL-60) cells is mediated through oxidative stress.

Methods: Human leukemia (HL-60) cells were treated with different concentrations of GE for $12 \mathrm{hr}$. Cell survival was determined by MTT assay. The extent of oxidative cell/tissue damage was determined by measuring malondialdehyde (lipid peroxidation biomarker) concentrations by spectrophotometry. Cell apoptosis was measured by flow cytometry assessment (Annexin- $V$ and caspase-3 assays) and agarose gel electrophoresis (DNA laddering assay).

Results: Data obtained from the MTT assay indicated that GE significantly $(p<0.05)$ reduced the viability of $\mathrm{HL}-60$ cells in a concentration-dependent manner. We detected a significant $(p<0.05)$ increase in malondialdehyde (MDA) concentrations in GE-treated HL-60 cells compared to the control. Flow cytometry data showed a strong concentration-response relationship between GE exposure and Annexin-V positive HL-60 cells. Similarly, a statistically significant and concentration-dependent increase $(p<0.05)$ were recorded with regard to caspase-3 activity in HL-60 cells undergoing late apoptosis. These results were confirmed by data of DNA laddering assay showing a clear evidence of nucleosomal DNA fragmentation in GE-treated cells.

Conclusion: Our finding indicates that GE-induced cytotoxicity and apoptosis in HL-60 cells involve phosphatidylserine externalization, caspase-3 activation, and nucleosomal DNA fragmentation associated with the formation of MDA, a by-product of lipid peroxidation and biomarker of oxidative stress. At therapeutic concentrations, GE-induced cytotoxic and apoptotic effects in HL-60 cells is mediated by oxidative stress.

Keywords: Garlic extract; HL-60 cells; Cell survival; Oxidative stress; Apoptosis

\section{Introduction}

Garlic is a vegetable that belongs to the Allium class of bulb-shaped plants, which also includes onions, chives, leeks, and scallions. It is widely consumed in many countries as spice and as condiment in many dishes, and for medicinal purposes. A laboratory study revealed that garlic extract contains high content of sulfur, arginine, oligosaccharides, flavonoids, and selenium, all of which are beneficial to human health [1]. In addition, crushed or processed garlic contains several organosulfur compounds such as allicin, diallyl sulfide, and diallyl disulfide which are valuable precursors for glutathione biosynthesis [2,3]. Ancient Egyptian records revealed that garlic is used as remedy for a variety of diseases [4]. Several in vivo studies indicate that garlic and sulfurcontaining garlic compounds suppress the incidence of tumors in rodent models [5-7]. Studies also indicate that sulfur-containing garlic compounds have anti-mutagenesis and anti-carcinogenesis effects [1]. Numerous pharmacological studies have demonstrated that garlic has many beneficial health effects [8-10]. Recently, consumption of allium vegetables, especially garlic and onions, has been linked to a reduced risk of stomach cancer [11]. Another study indicates that a greater intake of allium vegetables (more than $10 \mathrm{~g}$ per day vs. less than $2.2 \mathrm{~g}$ per day), particularly garlic and scallions, is associated with an approximately 50 percent reduction in prostate cancer risk [12].

Epidemiological studies, preclinical investigations and clinical trials support the role of garlic compounds as potent cancer chemopreventive agents. A recent report indicates that allicin (a biological active compound of garlic) induces mitochondrial release of cytochrome c, activation of caspase 9 and 3 and DNA fragmentation in U937 cells in a concentration-and time-dependent manner [13]. Although it is known that oxidative insults to DNA can lead to mutations in crucial genes, which may ultimately lead to cancer [14], one of the molecular mechanisms by which bioactive compounds induce cytotoxicity and apoptosis is through oxidative stress. Many studies have shown that garlic possesses antioxidant and anti-lipid peroxidative effects $[15,16]$ From recent study in Tunisia, Hamlaoui-Gasmi et al. [7] have reported that garlic could modulate oxidative stress in rats depending on its

*Corresponding author: Clement G. Yedjou, PhD, Assistant Professor Department of Biology, Jackson State University, 1400 Lynch Street, P.O. Box 18540, Jackson, Mississippi, USA, Tel: (601) 979-0215; Fax: (601) 979-5853; E-mail: clement.yedjou@jsums.edu

Received November 28, 2011; Accepted January 09, 2012; Published January 11, 2012

Citation: Yedjou CG, Tchounwou PB (2012) In vitro Assessment of Oxidative Stress and Apoptotic Mechanisms of Garlic Extract in the Treatment of Acute Promyelocytic Leukemia. J Cancer Sci Ther S3:006. doi:10.4172/1948-5956.S3006

Copyright: (c) 2012 Yedjou CG, et al. This is an open-access article distributed under the terms of the Creative Commons Attribution License, which permits unrestricted use, distribution, and reproduction in any medium, provided the original author and source are credited. 
route of administration. They have shown that oral administration of high dose of garlic increases antioxidant enzyme activity including catalase (CAT), peroxidase (POD) and superoxide dismutase (SOD) in rat brain. However, intraperitoneal administration of garlic increases MDA, $\mathrm{H}_{2} \mathrm{O}_{2}$ and $\mathrm{LDH}$ levels in brain on rats [17]. It has been also reported that aged garlic extract exerts its cancer-inhibitory action in different and complementary ways, due to the variety of compounds present in the extract [15]. Although published studies indicate that garlic has medicinal properties effective against many diseases other than leukemia, the molecular mechanisms under which this herbal medicine exerts its therapeutic effect in cancer cells remain largely unknown. Therefore, the present study was designed to use HL-60 cells as a test model to evaluate whether or not GE-induced cytotoxicty and apoptosis in human leukemia (HL-60) cells is mediated through oxidative stress.

\section{Materials and Methods}

\section{Chemicals and test media}

Growth medium RPMI 1640 containing 1mmol/L L-glutamine was purchased from Gibco BRL products (Grand Island, NY). Fetal bovine serum (FBS), phosphate buffered saline (PBS), and MTT assay kits were obtained from Sigma Chemical Company (St. Louis, MO). Lipid peroxidation kit was purchased from Calbiochem-Novabiochem (San Diego, CA). Annexin V fluorescein isothiocyanale (FITC) kit (contains annexin V FITC, binding buffer and propidium iodide [PI]), and active caspase-3 kit were obtained from BD Biosciences (Pharmingen, Becton Dickinson Co., San Diego, CA, USA).

\section{Preparation of garlic extract}

Garlic extract was prepared by homogenizing the required amount of garlic powder in an appropriate volume of distilled water to prepare a concentration of $100 \mathrm{mg} / \mathrm{mL}$. The homogenate was centrifuged at $3000 \mathrm{x} \mathrm{g}$ for $10 \mathrm{~min}$ to remove particulate matter and the supernatant fraction was used for the experiment. Garlic extract is composed of different biologically active molecules of health benefit [1].

\section{Tissue/cell culture}

Human leukemia (HL-60) cell line was purchased from the American Type Culture Collection - ATCC (Manassas, VA). This cell line has been derived from peripheral blood cells of a 36-year old Caucasian female with acute promyelocytic leukemia (APL). In the laboratory, cells were stored in the liquid nitrogen until use. They were next thawed by gentle agitation of their containers (vials) for 2 min in a water bath at $37^{\circ} \mathrm{C}$. After thawing, the content of each vial of cell was transferred to a $25 \mathrm{~cm}^{2}$ tissue culture flask, diluted with up to $10 \mathrm{~mL}$ of RPMI 1640 containing $1 \mathrm{mmol} / \mathrm{L}$ L-glutamine (GIBCO/ BRL, Gaithersburg, MD) and supplemented with $10 \%(\mathrm{v} / \mathrm{v})$ fetal bovine serum (FBS), 1\% (w/v) penicillin/streptomycin. The $25 \mathrm{~cm}^{2}$ culture flasks ( $2 \times 10^{6}$ viable cells) were observed under the microscope, followed by incubation in a humidified $5 \% \mathrm{CO}_{2}$ incubator at $37^{\circ} \mathrm{C}$. Three times a week, they were diluted under same conditions to maintain a density of $5 \times 10^{5} / \mathrm{mL}$, and harvested in the exponential phase of growth. The cell viability was assessed by the trypan blue exclusion test (Life Technologies), and manually counted using a hemocytometer.

\section{Cell treatment and biochemical test for cell viability}

The in vitro cytotoxicity and anti-cancer effect of garlic extract against HL-60 cells was determined by MTT assay [18]. Briefly, to 180 $\mu \mathrm{L}$ aliquots in six replicates of the cell suspension $\left(5 \mathrm{x} 10^{5}\right.$ cells $\left./ \mathrm{mL}\right)$ seeded to 96-well polystyrene tissue culture plates, $20 \mu \mathrm{L}$ aliquots of stock solutions were added to each well using distilled water as solvent to make-up final garlic extract (GE) concentrations of 2, 4, 6, 8, and 10 $\mathrm{mg} / \mathrm{mL}$. Control cells received $20 \mu \mathrm{L}$ of distilled water. Cells were placed in a humidified $5 \% \mathrm{CO}_{2}$ incubator for $12 \mathrm{hr}$ at $37^{\circ} \mathrm{C}$. After incubation, $20 \mu \mathrm{L}$ aliquots of MTT solution $(5 \mathrm{mg} / \mathrm{mL}$ in PBS) were added to each well and re-incubated for $4 \mathrm{~h}$ at $37^{\circ} \mathrm{C}$ following by low centrifugation at $800 \mathrm{rpm}$ for $5 \mathrm{~min}$. Then, the $200 \mu \mathrm{L}$ of supernatant culture medium were carefully aspirated and $200 \mu \mathrm{L}$ aliquots of dimethylsulfoxide (DMSO) were added to each well to dissolve the formazan crystals, followed by incubation for $10 \mathrm{~min}$ to dissolve air bubbles. The culture plate was placed on a Biotek micro-plate reader and the absorbance was measured at $550 \mathrm{~nm}$. All assays were performed in six replicates for each GE concentration. Statistical analysis was done to determine the means \pm SDs of cell viability. Cell viability rate was calculated as the percentage of MTT absorption as follows: \% survival $=$ (mean experimental absorbance/mean control absorbance $\times 100$ ).

\section{Biochemical test for oxidative stress by lipid peroxidation assay}

Lipid peroxidation is traditionally quantified to measure malondialdehyde (MDA) and 4-hydroxynonenal. The extraction procedure and measurement of the extracted MDA was performed according to the manufacturer's instructions (CalbiochemNovabiochem, San Diego, CA). Malondialdehydes (MDA) are formed during lipid peroxidation [19]. Briefly, $2 \times 10^{6} \mathrm{HL}-60$ cells $/ \mathrm{mL}$ untreated as a control and cells treated with garlic extract (GE) were incubated in a total volume of $10 \mathrm{ml}$ growth medium for $12 \mathrm{hr}$. After the incubation period, cells were collected in $15 \mathrm{~mL}$ tubes, followed by low-speed centrifugation. The cell pellets were re-suspended in $0.5 \mathrm{ml}$ of Tris-HCl, pH 7.4, and lysed using a sonicator (W-220; Ultrasonic, Farmingdale, NY) under the conditions of duty cycle-25\% and output control-40\% for $5 \mathrm{sec}$ on ice. A $200 \mu \mathrm{l}$ aliquot of the culture medium was assayed for MDA according to the lipid peroxidation assay kit protocol. The absorbance of the sample was read at $586 \mathrm{~nm}$, and the concentration of MDA was determined from a standard curve.

\section{Biochemical test for apoptosis detection by annexin V FITC/ PI assay}

To evaluate early apoptosis in human leukemia (HL-60) cells exposed to garlic extract (GE), we performed the flow cytometry assessment using annexin V FITC/PI staining kit. Annexin-V binds to cells that express phosphatidylserine on the outer layer of the cell membrane, and PI stains the cellular DNA of those that have a compromised cell membrane. This allows for the discrimination of live cells (unstained with either fluorochrome) from apoptotic cells (stained only with annexin-V) and necrotic cells (stained with both annexin-V and PI) [20]. Briefly, $1 \times 10^{6}$ cells $/ \mathrm{mL}$ were washed in PBS, re-suspended in binding buffer $(10 \mathrm{~mm}$ Hepes/NaOH pH 7.4, $140 \mathrm{~mm}$ $\mathrm{NaCl}, 2.5 \mathrm{~mm} \mathrm{CaCl}$ ), and stained with FITC-conjugated annexin $\mathrm{V}$ (Pharmingen, Becton Dickinson Co., San Diego, CA, USA). Then, cells were incubated for $15 \mathrm{~min}$ in the dark at room temperature, washed with binding buffer and analyzed by flow cytometry (FACS Calibur; Becton-Dickinson) using CellQuest software.

\section{Biochemical test for apoptosis detection by caspase- 3 assay}

Caspase-3 assay was carried out using a commercially available kit (Phycoerythrin-Conjugated Polyclonal Active Caspase-3 Antibody Apoptosis Kits, Pharmingen). HL-60 cells were grown in RPMI 1640 containing $1 \mathrm{mmol} / \mathrm{L}$ L-glutamine (GIBCO/BRL, Gaithersburg, MD) 
Citation: Yedjou CG, Tchounwou PB (2012) In vitro Assessment of Oxidative Stress and Apoptotic Mechanisms of Garlic Extract in the Treatment of Acute Promyelocytic Leukemia. J Cancer Sci Ther S3:006. doi:10.4172/1948-5956.S3-006

and supplemented with $10 \%(\mathrm{v} / \mathrm{v})$ fetal bovine serum (FBS), $1 \%(\mathrm{w} / \mathrm{v})$ penicillin/streptomycin. Two $\mathrm{mL}$ of cells $\left(1 \times 10^{6}\right.$ cells $\left./ \mathrm{mL}\right)$ were added to each well of 24 wells and treated with $2,4,6,8$, and $10 \mathrm{mg} / \mathrm{mL}$ of garlic extract (GE) for $12 \mathrm{hr}$. Control cells were processed exactly as GE-treated cells, except GE treatment of these cells was eliminated. Control and GE-treated cells were assayed for caspase-3-like protease according to a previously described protocol [21]. Briefly, $1 \times 10^{6}$ cells/ $\mathrm{mL}$ were washed per concentration with cold PBS ( $\mathrm{pH}$ 7.4). Washed cells were suspended in Cytofix/Cytoperm solutions and incubated for 20 min on ice. Cells were pelleted and washed with Perm/Wash buffer. Cells were then centrifuged at $3000 \mathrm{rpm}$ for $5 \mathrm{~min}$ and re-suspended in $0.2 \mathrm{~mL}$ Perm/Wash, $20 \mu \mathrm{L}$ PE- conjugaled polyclonal rabbit anti-active caspase-3 antibody and incubated at room temperature for $30 \mathrm{~min}$. Cells were re-suspended in $0.5 \mathrm{~mL}$ of perm/wash buffer and analyzed by flow cytometry (FACS Calibur; Becton-Dickinson) using CellQuest software.

\section{Biochemical test for apoptosis detection by agarose gel electrophoresis}

DNA fragmentation analysis was conducted to confirm the apoptotic mechanism of garlic extract (GE). Briefly, $2 \mathrm{~mL}$ of cells $(1 \times$ $10^{6}$ cells $/ \mathrm{mL}$ ) were added to each well of 24 wells and treated with 2,4 , 6,8 and $10 \mathrm{mg} / \mathrm{mL}$ of garlic extract (GE) for $12 \mathrm{hr}$. Control cells were processed exactly as GE-treated cells, except GE treatment of these cells was eliminated. After the incubation period, cellular DNA was extracted from whole cultured cells using genomic DNA isolation reagents from Roche Molecular Biochemicals (Indianapolis, IN) according to the manufacturer's protocol. Extracted DNA samples were placed into the well of agarose gel. The agarose gels were run at 75 volts until the purple tracer marker migrated to approximately $2 \mathrm{~cm}$ before the end of the gel. After electrophoresis, the gel was stained with ethidium bromide, and photographed under UV light [22].

\section{Statistical analysis}

Experiments were performed in triplicates. Data were presented as means \pm SDs. Where appropriate, one-way ANOVA or Student paired t-test was performed using SAS Software available in the Biostatistics Core Laboratory at Jackson State University. $P$-values less than 0.05 were considered statistically significant.

\section{Results}

\section{Inhibition of HL-60 cells proliferation by garlic extract}

We used the MTT assay to examine the cytotoxic effect of garlic extract (GE) on HL-60 cells for $12 \mathrm{hr}$ (Figure 1). Data generated from these experiments clearly showed that GE exposure significantly reduces the viability of HL-60 cells in a concentration-dependent fashion. Higher percentages of non-viable cells were noted in cells cultured at high GE concentrations within the range doses of 8 and 10 $\mathrm{mg} / \mathrm{mL}$.

\section{Induction of malondialdehyde (MDA) production in HL-60 cells by garlic extract}

Oxidative stress constitutes one of the molecular mechanisms by which bioactive compounds induce cytotoxicity and apoptosis. To determine the extent of oxidative cell damage in HL-60 cells exposed to garlic extract (GE), we performed lipid peroxidation assay. Our result obtained from this assay showed a significant $(p<0.05)$ increase in malondialdehyde (a by-product of lipid peroxidation and biomarker of oxidative stress) concentrations in GE-treated HL-60 cells compared to the control. A maximum level $(27.75 \mu \mathrm{M})$ of malondialdehyde (MDA) production in HL-60 cells was observed at $6 \mathrm{mg} / \mathrm{mL}$ of GE exposure compared to $(18.75 \mu \mathrm{M})$ in the control. This increase demonstrates that GE augments MDA production in HL- 60 cells by $48 \%$ at $6 \mathrm{mg} / \mathrm{mL}$ of exposure when compared to the control (Figure 2).

\section{Modulation of phosphotidylserine externalization in HL-60 cells by garlic extract}

Flow cytometry analysis was performed to investigate the apoptotic effects of garlic extract (GE) on HL-60 cells. Cells were dual-stained with Annexin V-FITC and propidium iodide (PI). The percentage of apoptotic cells in the control, and cells treated with GE were $5.0 \pm 0.0 \%$, $11.5 \pm 2.1 \%, 18.0 \pm 1.4 \%, 22.5 \pm 0.7,17.5 \pm 2.1$ and $15.0 \pm 1.4 \%$ in $0,2,4,6,8 \mathrm{mg} / \mathrm{mL}$ respectively (Figures 3,5 ). GE-treated HL-60 cells were significantly different $(P<0.05)$ compared to the control group according to ANOVA Dunnett's test.

\section{Activation of caspase- 3 in HL-60 cells by garlic extract}

The activity of caspase-3 in human leukemia (HL-60) cells exposed

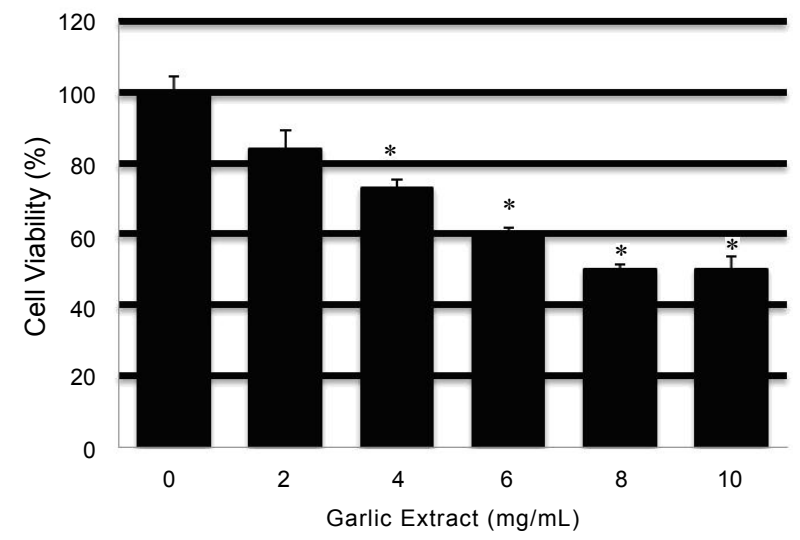

Figure 1: Cytotoxic effect of garlic extract to human leukemia (HL-60) cells. HL60 cells were cultured with increasing concentrations of garlic extract $(2,4,6,8$, and $10 \mathrm{mg} / \mathrm{mL}$ ) for $12 \mathrm{hr}$ as indicated in the Materials and Methods. Cell viability was determined based on the MTT assay. Each point represents a mean \pm SD of 3 experiments with 6 replicates per dose. *Significantly different $(p<0.05)$ from the control, according to the Dunnett's test.

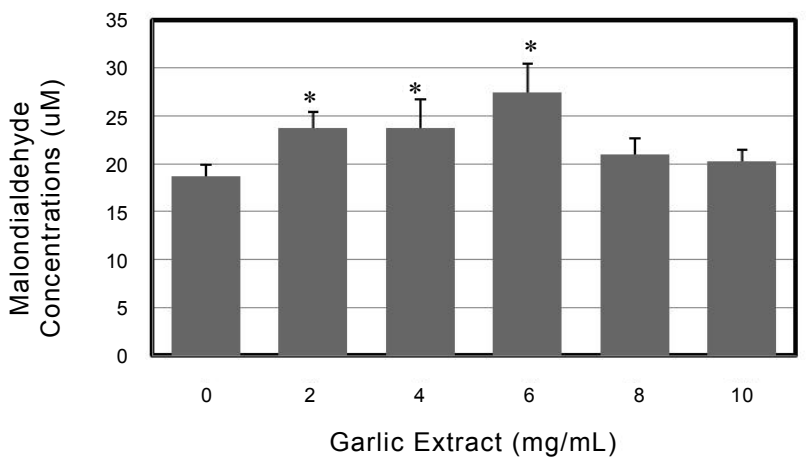

Figure 2: Garlic extract (GE)-induced oxidative stress in human leukemia (HL-60) cells. Cells were incubated for $12 \mathrm{hr}$ with increasing concentrations of $\mathrm{GE}(2,4,6,8$, and $10 \mathrm{mg} / \mathrm{mL})$. Malondialdehyde (MDA) concentrations were determined as described in Materials and Methods. *Significantly different from the control by ANOVA Dunnett's test; $P<0.05$. Data are representative of 3 independent experiments. 
Citation: Yedjou CG, Tchounwou PB (2012) In vitro Assessment of Oxidative Stress and Apoptotic Mechanisms of Garlic Extract in the Treatment of Acute Promyelocytic Leukemia. J Cancer Sci Ther S3:006. doi:10.4172/1948-5956.S3-006

Page 4 of 7

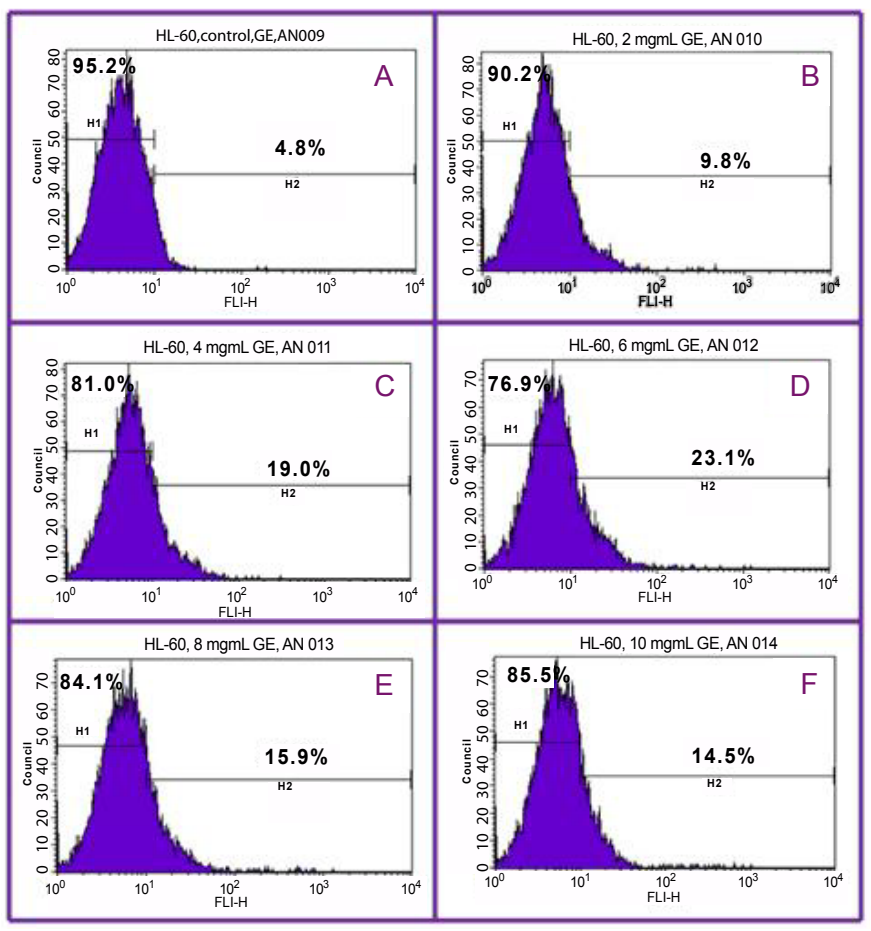

Figure 3: Representative flow cytometry analysis data from Annexin V-FITC/ $\mathrm{Pl}$ assay. The histograms show a comparison of the distribution of annexin $\mathrm{V}$ negative cells (M1) and annexin $V$ positive cells (M2) after $12 \mathrm{hr}$ exposure to garlic extract. $A=$ control; $B=2 \mathrm{mg} / \mathrm{mL} ; C=4 \mathrm{mg} / \mathrm{mL} ; \mathrm{D}=6 \mathrm{mg} / \mathrm{mL} ; \mathrm{E}=8 \mathrm{~g} /$ $\mathrm{mL} ;$ and $\mathrm{F}=10 \mathrm{mg} / \mathrm{mL}$.

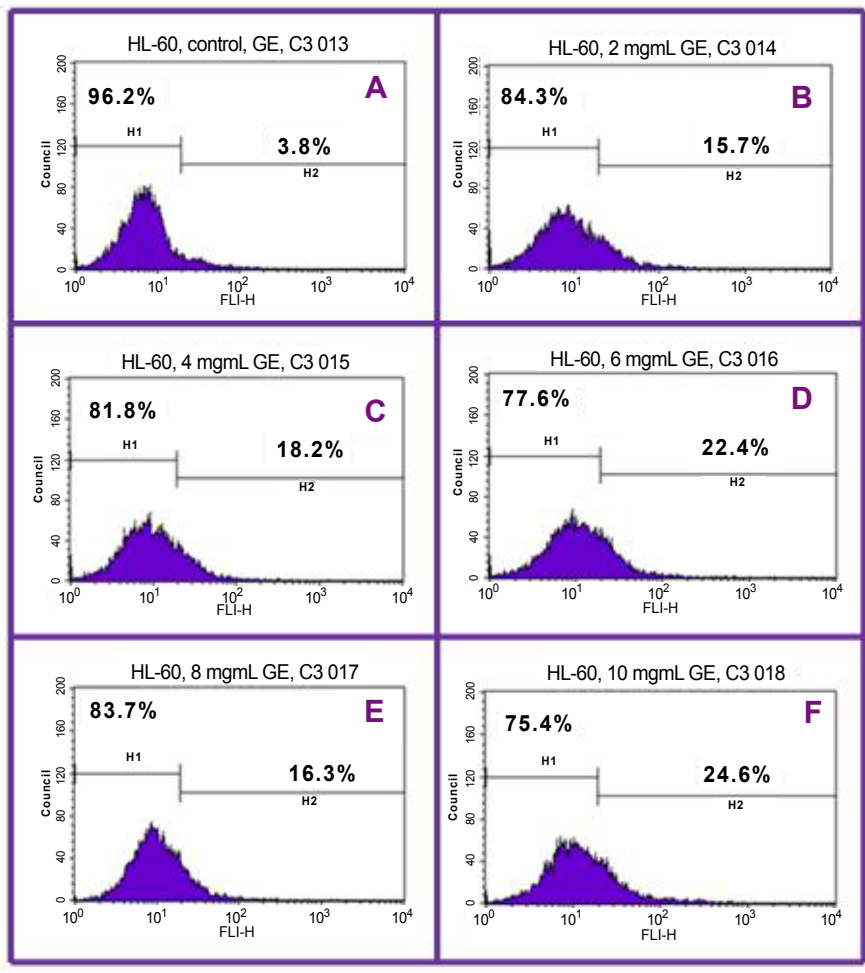

Figure 4: Representative flow cytometry analysis data from caspase-3 assay. The histograms show a comparison of the distribution of caspase- 3 negative cells (M1) and caspase- 3 positive cells (M2) after $12 \mathrm{hr}$ exposure to garlic extract. $A=$ control; $B=2 \mathrm{mg} / \mathrm{mL} ; C=4 \mathrm{mg} / \mathrm{mL} ; \mathrm{D}=6 \mathrm{mg} / \mathrm{mL} ; \mathrm{E}=8 \mathrm{mg} / \mathrm{mL}$, and $\mathrm{F}=10 \mathrm{mg} / \mathrm{mL}$ to garlic extract (GE) was assessed by flow cytometry. As seen in Figure 3 , there was a strong concentration-response relationship between caspase- 3 activation in HL-60 cells and GE exposure. After $12 \mathrm{hr}$ of exposure, the percentages of caspase- 3 positive cells (apoptotic cells) were $7.5 \pm 0.7 \%, 12.0 \pm 4.0 \%, 15.5 \pm 3.5 \%, 21.0 \pm 1.4 \%, 19.5 \pm 2.8$, and $19.5 \pm 6.2 \%$ in $0,2,4,6$, and $8 \mathrm{mg} / \mathrm{mL}$ of GE, respectively (Figures 4,5 ). GE-treated HL-60 cells were significantly different $(P<0.05)$ compared to the control group according to ANOVA Dunnett's test.

\section{Induction of nucleosomal DNA fragmentation in HL-60 cells by garlic extract}

Agarose gel electrophoresis of DNA extracted from control and garlic extract (GE)-treated cells is presented in (Figure 6). As shown on this figure, our result showed positive nucleosomal DNA fragmentation in nuclei isolated from human leukemia (HL-60) cells. A small fragment of DNA double-strand breaks was detected in cells incubated in the absence of GE. Overall, the present observation demonstrates that GE induces nucleosomal DNA fragmentation in human leukemia (HL-60) cells.

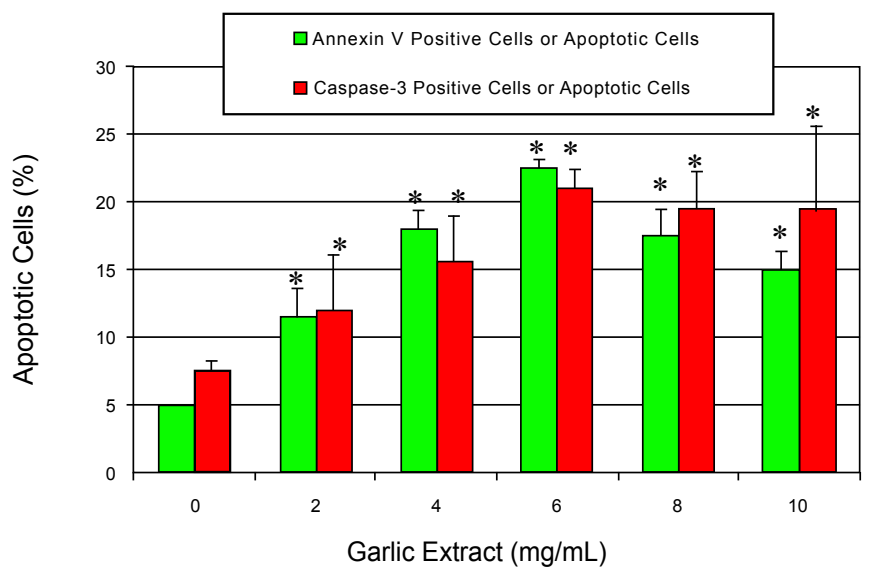

Figure 5: Proportion of annexin $\mathrm{V}$ positive cells (green) and caspase-3 positive cells (red) in garlic extract-treated HL-60 cells. Human leukemia (HL-60) cells were cultured in the absence or presence of garlic extract for $12 \mathrm{hr}$ as indicated in the Materials and Methods. Values are shown as means \pm SDs of 3 replicates per experiment. *Significantly different at $p<0.05$ to the control group.

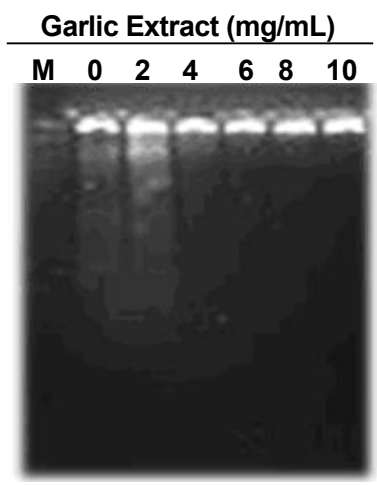

Figure 6: DNA fragmentation in human leukemia (HL-60) cells exposed to garlic extract (GE) at $0 \mathrm{mg} / \mathrm{mL}$ (control with no GE treatment), $2 \mathrm{mg} / \mathrm{mL}, 4 \mathrm{mg} /$ $\mathrm{mL}, 6 \mathrm{mg} / \mathrm{mL}, 8 \mathrm{mg} / \mathrm{mL}$, and $10 \mathrm{mg} / \mathrm{mL}$ GE. M denotes the molecular weight marker. Twelve (12) $\mu \mathrm{L}$ of each sample was electrophoresed on a $1.2 \%$ agarose as described in Materials and Methods. DNA was stained with ethidium bromide and then visualized under UV light. 


\section{Discussion}

Garlic (Allium sativum) and its constituents have been widely used as therapeutic agents for prevention and treatment of cancer, diabetes, cardiovascular diseases and other metabolic diseases such as atherosclerosis, hyperlipidemia, thrombosis, hypertension, and dementia [23]. Experimental and clinical studies indicate that garlic reduces the cancer risk by inhibiting carcinogen activation and/or increasing detoxification of activated carcinogens, and exhibiting antitumor activities $[4,24,25]$. This compound also reduces the risk of cardiovascular diseases by lowering the serum cholesterol level [8], inhibiting platelet aggregation [26] and increasing fibrinolysis [27]. In the present study, we used the MTT assay to examine the cytotoxic effect of garlic extract (GE) on HL-60 cells. Data generated from this assay indicated that GE exposure significantly $(p<0.05)$ reduces the viability of HL-60 cells in a concentration-dependent fashion (Figure 1). In support of our findings, previous in vitro studies have indicated that derivatives of garlic inhibit proliferation of a human cervical cancer (HeLa) cells [28], human prostate cancer cells and human breast cancer cells [29]. Several population studies conducted in China have shown an association between increased intake of garlic and reduced risk of cancers of the stomach, colon, esophagus, pancreas, and breast $[3,30]$. A recent study conducted in the San Francisco Bay area has reported that pancreatic cancer risk is 54 percent lower in people who ate larger amounts of garlic compared with those who ate lower amounts [31]. The biologically active molecules of garlic that are beneficial to human health include sulfur, arginine, oligosaccharides, flavonoids, and selenium [1]. Futhermore, processed garlic contains many organosulfur compounds such as allicin, diallyl sulfide, and diallyl disulfide $[2,3]$.

To evaluate whether GE-induced cytotoxicty and apoptosis in human leukemia (HL-60) cells is mediated by oxidative stress, we performed lipid peroxidation assay. Our result obtained from this assay showed a significant $(p<0.05)$ increase in malondialdehyde (a by-product of lipid peroxidation and biomarker of oxidative stress) concentrations in GE-treated HL-60 cells compared to the control. We observed a maximum level $(27.75 \mu \mathrm{M})$ of malondialdehyde (MDA) production in HL- 60 cells at $6 \mathrm{mg} / \mathrm{mL}$ of GE exposure compared to $(18.75 \mu \mathrm{M})$ in the control. This increase demonstrates that GE augments MDA production in HL- 60 cells by $48 \%$ at $6 \mathrm{mg} / \mathrm{mL}$ of exposure when compared to the control (Figure 2). Similarly, Dirsch and collaborators reported that treatment of HL-60 cells with ajoene (a major component of garlic) caused a dose- and time-dependent increase in peroxide production [32]. Ajoene has been shown to induce apoptosis in human promyelocytic leukemic cells through the generation of reactive oxygen species (ROSs) and activation of nuclear factor- $\mathrm{kB}$ [32]. In addition, a recent study indicated that garlic compounds generate reactive oxygen species leading to activation of stress kinases and cysteine proteases for apoptosis in human glioblastoma T98G and U87MG Cells [33]. A study from our laboratory indicated ascorbic acid enhanced the activity of arsenic trioxide in treated HL-60 cells by increasing its cytotoxic effect and inducing the production of malondialdehyde [34]. Clinical studies reported that drugs such as cloroquin, quinine, mefloquine, primaquin, artemisinin, and aprofloxanin act by the mechanisms of oxidative stress $[35,36]$.

Garlic has also been reported to have antioxidant properties which scavenge the reactive oxygen species (ROS), enhancing the cellular antioxidant enzymes (superoxide dismutase, catalase, glutathione peroxidase) thereby protecting the cells against disease-causing oxidative damage [37]. Recently, Rahman et al. [38] have reviewed the literature on clinical trials related to the antioxidant properties of garlic and discovered seven (7) published studies since 1993. They reported that five of the studies showed a decrease in oxidative stress [39-41] while two other studies showed no significant change in oxidative stress parameters $[42,43]$. Further clinical trials are needed to confirm the antioxidant properties of garlic.

However, administration of garlic can alter the activities of endogenous antioxidants, depending on the dosage and type of antioxidants [44]. For example, a study by Banerjee et al. [37] has shown that use of garlic at low doses could significantly increase superoxide dismutase (SOD), whereas at higher doses, the activity of SOD is reduced. Interestingly, we have demonstrated for the first time in the present study that GE treatment of HL-60 cells causes increase in the production of MDA, a biomarker of oxidative stress and cell injury. MDA production detected in the present study may be indicative of the therapeutic mechanism of action of garlic compound in cancer cells.

To better understand the mechanism of GE-induced apoptosis, we examined the modulation of phosphatidylserine externalization in HL-60 cells by flow cytometry. We observed that GE induces cellular apoptosis in human leukemia (HL-60) cells in a concentrationdependent manner, showing an increase expression of annexin positive cells in GE-treated cells compared to the control (Figure 3). The effect of GE was more powerful at $6 \mathrm{mg} / \mathrm{mL}(P<0.05)$ compared to the control cells. We found that the percentage of annexin positive cells (apoptotic cells) increased gradually $(P<0.05)$ in a concentration-dependent manner with increasing GE concentrations and reached a maximum of $22.5 \pm 0.7 \%$ cell death at $6 \mathrm{mg} / \mathrm{mL}$ after $12 \mathrm{hr}$ of exposure. Above 6 $\mathrm{mg} / \mathrm{mL}$ exposure, GE failed to further increase apoptosis, probably due to the high level of cell death at/or above $8 \mathrm{mg} / \mathrm{mL}$ of exposure (Figure 3). Consistently, previous studies had reported that garlic inhibits the growth of human colon, lung and skin cancer cells and induces apoptosis by increasing intracellular calcium concentrations in human colon tumor cells [45]. Biologically active compounds of garlic, such as allicin, induce apoptosis in human epithelial carcinoma through a caspase-independent pathway, mediated by the release of apoptoticinducing factor (AIF) from mitochondria and protein kinase A (PKA) activation [46]. However, the mechanism underlying the induction of cell death by GE has not been fully elucidated.

To further understand or gain insight into the mechanism of GEinduced apoptosis, we examined caspase- 3 activation in HL-60 cells. Caspase- 3 is a protein which has been shown to play a pivotal role in the execution phase of apoptosis induced by diverse stimuli [47]. As shown on Figure 4, we have demonstrated that GE significantly induces apoptosis of HL-60 cells in a concentration-dependent manner, at least in part, through activation of caspase-3. We have found that the percentages of caspase-3 positive cells (apoptotic cells) increased gradually with increasing GE concentrations and reached a maximum of $21.0 \pm 1.4 \%$ cell death at $6 \mathrm{mg} / \mathrm{mL}$ after $12 \mathrm{hr}$ of exposure. Above $6 \mathrm{mg} / \mathrm{mL}$ exposure, GE failed to further increase apoptosis, probably due to the high level of cell death at/or above $8 \mathrm{mg} / \mathrm{mL}$ of exposure (Figure 4). This study suggests that active caspase- 3 plays an important role in executing apoptosis in GE-treated HL-60 cells. Consistent with our results, previous reports had indicated that diallyl disulfide (a major component of garlic compound) induces apoptosis of human leukemia HL-60 cells and triggers hydrogen peroxide generation, activate caspase- 3 , and degrade poly(ADP-ribose) polymerase and fragmentation of DNA [48-50]. Taken together, the flow cytometry data demonstrated that treatment of cells with $6 \mathrm{mg} / \mathrm{mL}$ GE is the optimum concentration to induce cell apoptosis (Figure 5). 
Citation: Yedjou CG, Tchounwou PB (2012) In vitro Assessment of Oxidative Stress and Apoptotic Mechanisms of Garlic Extract in the Treatment of Acute Promyelocytic Leukemia. J Cancer Sci Ther S3:006. doi:10.4172/1948-5956.S3-006

To confirm the apoptotic mechanism of garlic extract (GE) for the above results, we further examined the apoptotic response, as judged by the appearance of a DNA ladder through agarose gel electrophoresis. We observed DNA ladders in extracts from HL-60 cells treated with GE at concentrations of 2, 4, 6, 8 and $10 \mathrm{mg} / \mathrm{mL}$ for $12 \mathrm{~h}$. Consistent with our finding, recent study indicated that allicin (a biological active compound of garlic) induced mitochondrial release of cytochrome $\mathrm{c}$, activation of caspases 9 and 3 and DNA fragmentation in HL-60 and U937 cells in a concentration-and time-dependent manner [13]. DNA Ladder is a characteristic pattern of nucleosomal DNA fragmentation, which is the hallmark of apoptosis. DNA fragmentation is one of the later stages of apoptosis [51]. Overall, data generated from the flow cytometry assessment (Figure 5) and DNA laddering assay (Figure 6) support the notion that apoptosis may be a potential mechanism of garlic action against human leukemia cancer.

\section{Conclusion}

In the present study, we examined the molecular basis of garlic extract (GE) in vitro. Our results indicate that GE-induced cytotoxicity and apoptosis in HL-60 cells are associated with malondialdehyde formation, phosphatidylserine externalization, caspase-3 activation, nucleosomal DNA fragmentation, and cell death. Although the mechanisms under which GE exerts its therapeutic effect in human cancers remain largely unknown, we have demonstrated in the present study that oxidative stress may be the potential mechanism for the antiproliferative effects and apoptosis of garlic extract, suggesting its potential chemo-preventive action in patients with acute promyelocytic leukemia. Here, we also demonstrate in part the molecular mechanism responsible for causing cell death and apoptosis after treating cells with GE. However, further in vitro and in vivo investigations are needed to understand the precise mechanisms regulating the antiproliferative effects and apoptosis induced by garlic.

\section{Acknowledgements}

The research described in this publication was made possible by a gran from the National Institutes of Health (Grant No. 5G12RR013459-13), through the RCMI-Center for Environmental Health at Jackson State University. An ora presentation based on this paper was presented at the $8^{\text {th }}$ International Symposium on Environmental Research and public Health.

\section{Conflict of Interest}

No authors have any conflict of interest relevant to this work. CG Yedjou has performed the experiments and drafted the manuscript that was reviewed by PB Tchounwou. PB Tchounwou also supervised the experiments, and assisted in performing the statistical analysis and data interpretation.

\section{References}

1. Milner JA (1996) Garlic: its anticarcinogenic and antitumorigenic properties Nutr Rev 54: S82-S86.

2. Wei Z, Lau BH (1998) Garlic inhibits free radical generation and augments antioxidant enzyme activity in vascular endothelial cells. Nutr Res 18: 61-70.

3. Fleischauer AT, Arab L (2001) Garlic and cancer: a critical review of the epidemiologic literature. J Nutr 131: 1032S-1040S.

4. Block E (1985) The chemistry of garlic and onions. Sci Am 252: 114-119.

5. Liu J, Lin RI, Milner JA (1992) Inhibition of 7,12-dimethylbenz[a]anthraceneinduced mammary tumors and DNA adducts by garlic powder. Carcinogenesis 13: $1847-1851$

6. Amagase H, Milner JA (1993) Impact of various sources of garlic and their constituents on 7,12-dimethylbenz[a]anthracene binding to mammary cell DNA. Carcinogenesis 14: 1627-1631.

7. Song K, Milner JA (1999) Heating garlic inhibits its ability to suppress 7 12-dimethylbenz(a)anthracene-induced DNA adduct formation in rat mammary tissue. J Nutr 129: 657-661.
8. Steiner M, Lin RS (1998) Changes in platelet function and susceptibility of lipoproteins to oxidation associated with administration of aged garlic extract. J Cardiovasc Pharmacol 31: 904-908.

9. Kojuri J, Vosoughi AR, Akrami M (2007) Effects of anethum graveolens and garlic on lipid profile in hyperlipidemic patients. Lipids Health Dis 1: 5.

10. Rahman K (2007) Effects of garlic on platelet biochemistry and physiology. Mo Nutr Food Res 51: 1335-1344.

11. Setiawan VW, Yu GP, Lu QY, Lu ML, Yu SZ, et al. (2005) Allium vegetables and stomach cancer risk in China. Asian Pac J Cancer Prev 6: 387-395.

12. Hsing AW, Chokkalingam AP, Gao YT, Madigan MP, Deng J, et al. (2002) Allium vegetables and risk of prostate cancer: a population-based study. J Nat Cancer Inst 94: 1648-1651.

13. Miron T, Wilchek M, Sharp A, Nakagawa Y, Naoi M, et al. (2008) Allicin inhibits cell growth and induces apoptosis through the mitochondrial pathway in HL60 and U937 cells. J Nutr Biochem 19: 524-535

14. Ames BN, Shigenaga MK, Hagen TM (1993) Oxidants, antioxidants, and the degenerative diseases of aging. Proc Natl Acad Sci USA 90: 7915-7922.

15. Borek C (2001) Antioxidant health effects of aged garlic extract. J Nutr 131: 1010S-1015S.

16. Amagase H (1998) Intake of garlic and its bioactive components. Nutritional and health benefeits of garlic as a supplement conference. Newport Beach CA, USA.

17. Hamlaoui-Gasmi S, Limam N, Mokni M, Limam F, Aouani E, et al. (2011) Garlic-mode treatment effects on rat brain redox status. J Med Plants Res 5 5094-5098.

18. Yedjou CG, Tchounwou PB (2007) In-vitro cytotoxic and genotoxic effects of arsenic trioxide on human leukemia (HL-60) cells using the MTT and alkaline single cell gel electrophoresis (Comet) assays. Mol Cell Biochem 301: 123-130.

19. Halliwell B, Gutteridge JM (1984) Oxygen toxicity, oxygen radicals, transition metals and disease. Biochem J 219: 1-14

20. Vermes I, Haanen C, Steffens-Nakken H, Reutelingsperger C (1995) A novel assay for apoptosis. Flow cytometric detection of phosphatidylserine expression on early apoptotic cells using fluorescein labelled Annexin V. J Immunol Methods 184: 39-51.

21. Belloc F, Belaud-Rotureau MA, Lavignolle V, Bascans E, Braz-Pereira E, et al. (2000) Flow cytometry detection of caspase 3 activation in preapoptotic leukemic cells. Cytometry 40: 151-160.

22. Yeung MC (2002) Accelerated apoptotic DNA laddering protocol. Biotechniques 33: 734-736.

23. Lawson LD (1998) Garlic: a review of its medicinal effects and indicated active compounds. Phytomedicines of Europe 691: 176-209.

24. Yang CS, Chhabra SK, Hong JY, Smith TJ (2001) Mechanisms of inhibition of chemical toxicity and carcinogenesis by diallyl sulfide (DAS) and related compounds from garlic. J Nutr 131: 1041-1045.

25. Milner JA (2001) Mechanisms by which garlic and allyl sulfur compounds suppress carcinogen bioactivation. Garlic and carcinogenesis. Adv Exp Med Biol 492: 69-81.

26. Agarwal KC (1996) Therapeutic actions of garlic constituents. Med Res Rev 16: $111-124$

27. Rahman K (2001) Historical perspective on garlic and cardiovascular disease. J Nutr 131: 977 S-979S.

28. Weber ND, Andersen DO, North JA, Murray BK, Lawson LD, et al. (1992) In vitro virucidal effects of Allium sativum (garlic) extract and compounds. Planta Med 58: 417-423.

29. Pinto JT, Rivlin RS (2001) Antiproliferative effects of allium derivatives from garlic. J Nutr 131: 1058S-1060S.

30. Gao CM, Takezaki T, Ding JH, Li MS, Tajima K (1999) Protective effect of allium vegetables against both esophageal and stomach cancer: a simultaneous case-referent study of a high-epidemic area in Jiangsu Province, China. Jpn J Cancer Res 90: 614-621.

31. Chan JM, Wang F, Holly EA (2005) Vegetable and fruit intake and pancreatic cancer in a population-based case-control study in the San Francisco bay area. Cancer Epidemiol Biomarkers Prev 14: 2093-2097. 
Citation: Yedjou CG, Tchounwou PB (2012) In vitro Assessment of Oxidative Stress and Apoptotic Mechanisms of Garlic Extract in the Treatment of Acute Promyelocytic Leukemia. J Cancer Sci Ther S3:006. doi:10.4172/1948-5956.S3-006

Page 7 of 7

32. Dirsch VM, Gerbes AL, Vollmar AM (1998) Ajoene, a compound of garlic, induces apoptosis in human promyeloleukemic cells, accompanied by generation of reactive oxygen species and activation of nuclear factor kappaB. Mol Pharmacol 53: 402-407.

33. Das A, Banik NL, Ray SK (2007) Garlic compounds generate reactive oxygen species leading to activation of stress kinases and cysteine proteases for apoptosis in human glioblastoma T98G and U87MG cells. Cancer 110: 10831095.

34. Yedjou C, Thuisseu L, Tchounwou C, Gomes M, Howard C, et al. (2009) Ascorbic Acid Potentiation of Arsenic Trioxide Anticancer Activity Against Acute Promyelocytic Leukemia. Arch Drug Inf 2: 59-65.

35. Tracy JW, Webster LT (2001) Drugs Used in the Chemotherapy of Protozoal Infections. In: Good-man and Gilmans the Pharmacological Basis of Therapeutics, Joel, GH and LE Limbird (Eds) (10 $10^{\text {th }}$ Edn), McGraw Hill, New York, 1097-1120.

36. Becerra MC, Albesa I (2002) Oxidative stress induced by ciprofloxacin in Staphylococcus aureus. Biochem Biophys Res Commun 297: 1003-1007.

37. Banerjee SK, Dinda AK, Manchanda SC, Maulik SK (2002) Chronic garlic administration protects rat heart against oxidative stress induced by ischemic reperfusion injury. BMC Pharmacol 2: 16.

38. Rahman K, Lowe GM (2006) Garlic and cardiovascular disease: a critical review. J Nutr 136: 736S-740S.

39. Durak I, Kavutcu M, Aytaç B, Avci A, Devrim E, et al. (2004) Effects of garlic extract consumption on blood lipid and oxidant/antioxidant parameters in humans with high blood cholesterol. J Nutr Biochem 15: 373-377.

40. Dhawan V, Jain S (2004) Effect of garlic supplementation on oxidized low density lipoproteins and lipid peroxidation in patients of essential hypertension. Mol Cell Biochem 266: 109-115.

41. Dillon SA, Lowe GM, Billington D, Rahman K (2002) Dietary supplementation with aged garlic extract reduces plasma and urine concentrations of 8-iso- prostaglandin $\mathrm{F}(2$ alpha) in smoking and nonsmoking men and women. J Nutr 132: 168-171.

42. Byrne DJ, Neil HA, Vallance DT, Winder AF (1999) A pilot study of garlic consumption shows no significant effect on markers of oxidation or sub-fraction composition of low-density lipoprotein including lipoprotein(a) after allowance for non-compliance and the placebo effect. Clin Chim Acta 285: 21-33.

43. Banerjee SK, Maulik SK (2002) Effect of garlic on cardiovascular disorders: a review. Nutr J 1: 4

44. Hammami I, Nahdi A, Mauduit C, Benahmed M, Amri M, et al. (2008) The inhibitory effects on adult male reproductive functions of crude garlic (Allium sativum) feeding. Asian J Androl 10: 593-601.

45. Sundaram SG, Milner JA (1996) Diallyl disulfide induces apoptosis of human colon tumor cells. Carcinogenesis 17: 669-673.

46. Park SY, Cho SJ, Kwon HC, Lee KR, Rhee DK, et al. (2005) Caspaseindependent cell death by allicin in human epithelial carcinoma cells: involvement of PKA. Cancer Lett 224: 123-132.

47. Lockshin RA, Zakeri Z (2002) Caspase-independent cell deaths. Curr Opin Cel Biol 14: 727-733.

48. Zheng S, Yang H, Zhang S, Wang X, Yu L, et al. (1997) Initial study on naturally occurring products from traditional Chinese herbs and vegetables for chemoprevention. J Cell Biochem Suppl 27: 106-112.

49. Zheng S, Yang H, Zhang S, Wang X, Yu L, et al. (2000) Erratum. J Cell Biochem 77: 125.

50. Kwon KB, Yoo SJ, Ryu DG, Yang JY, Rho HW, et al. (2002) Induction of apoptosis by diallyl disulfide through activation of caspase-3 in human leukemia HL-60 cells. Biochem Pharmacol 63: 41-47.

51. Saraste A, Pulkki K (2000) Morphologic and biochemical hallmarks of apoptosis. Cardiovasc Res 45: 528-537.
This article was originally published in a special issue, Cancer

Chemoprevention handled by Editor(s). Dr. Rajendra Sharma, University of North Texas, USA 